\title{
Effects of Soil and Rock Mineralogy on Soil Erosion Features in the Merek Watershed, Iran
}

\author{
Mosayeb Heshmati $^{{ }^{*}}$, Nik M. Majid ${ }^{2}$, Shamshuddin Jusop ${ }^{2}$, Mohamad Gheitury ${ }^{1}$, Arifin Abdu ${ }^{2}$ \\ ${ }^{1}$ Department of Watershed Management, Agriculture and Natural Research Center, Kermanshah, Iran \\ ${ }^{2}$ Department of Forest Management, Faculty of Forestry, Universiti Putra Malaysia, Serdang, Malaysia \\ Email: "heshmati46@gmail.com, nik@putra.upm.edu.my,mghatori50@yahoo.com, samsudin@agri.upm.edu.my
}

Received December 6, 2012; revised February 22, 2013; accepted March 25, 2013

Copyright (C) 2013 Mosayeb Heshmati et al. This is an open access article distributed under the Creative Commons Attribution License, which permits unrestricted use, distribution, and reproduction in any medium, provided the original work is properly cited.

\begin{abstract}
Accelerated soil erosion is anthropogenic phenomenon and a major worldwide environmental problem. It mainly leads to removal of the clay minerals and soil nutrients and thereby reduces soil fertility because of mineralogical influence on the soil. The objectives of this study were to identify the dominant soil and rock minerals and the influences of mineralogical properties on soil erosion features. This study was conducted at the Merek watershed, located in Kermanshah, Iran. There are different geological formations comprising limestone, sandstone, radiolarite, flysch, shale and marl. The border of each formation was mapped based on geology map and was checked in the field, using GPS and digitized by GIS software (ILWIS 3.5). The erosion feature map was prepared through remotely sensed data (Landsat ETM+ 2002, Path/Row and acquired date). About 300 soil and 28 rock samples were collected from the study area for soil and mineralogy analysis. Result shows that inter-rill, rill and snow erosion were occurred mainly at soil from Sarvak, Ilam and Gurpi Formation which are mainly containing calcite, dolomite, quartz and caolinite minerals giving moderate soil erosion intensity $\left(5-10 \mathrm{t} \cdot \mathrm{ha}^{-1} \cdot \mathrm{yr}^{-1}\right)$. Whereas mica/smectite was dominant clay mineral of soil from Older Terraces resulting in gully erosion and considerable $12.90 \mathrm{t} \cdot \mathrm{ha}^{-1} \cdot \mathrm{yr}^{-1}$ soil loss. Furthermore, smectite was found as the dominant clay mineral from both soil and parent material of Kashkan Formation (marls material) contributing to landslide occurrence and severe annual soil erosion $\left(16.6 \mathrm{t}^{\mathrm{ha}} \mathrm{h}^{-1} \cdot \mathrm{yr}^{-1}\right)$. This study revealed that both soil erosion feature and intensity potentially are affected by mineralogical properties.
\end{abstract}

Keywords: Erosion Feature; Merek Watershed; Soil Mineralogy; X-Ray Diffractogram

\section{Introduction}

Accelerated soil erosion is anthropogenic phenomenon and consequently a major worldwide environmental problem. It mainly leads to removal of the soil materials and nutrients and thereby reduces soil fertility. In addition, the mechanical characteristics such as liquid limit, plasticity limit and specific surface area exert strong influence on crack tension and slab failure in gully erosion when clay content reaches more than $30 \%[1,2]$. Smectite and vermiculite are the dominant minerals in marl, shale and mudstone in southwestern of Iran [3].

Smectite is important clay mineral in terms of erosion, sedimentation and landslide occurrence but it contributes the soil a high CEC. It also gives a high erodibility to the soils due to its unique characteristics mainly weak interlayer bonding, high swelling and cracking potential and

"Corresponding author. high water adsorption capacity. It can expand up to $30 \%$ in volume for water absorption contributing to creeping, piping, landslide and gully erosion [4-6]. Vermiculite is one of the common soil minerals in the semiarid region affecting soil erosion such as gully erosion in the arable lands. The low occurrence of vermiculite in the calcareous soils is mainly related to its lower stability under high $\mathrm{pH}$, low $\mathrm{Al}$ activity and the presence of large amounts of Si and $\mathrm{Mg}$ in soils [7].

The relatively sufficient annual rainfall (about $500 \mathrm{~mm}$ ) in the semi-arid region of Iran resulted in high water adsorption, soil swelling and subsequently landslide occurrence, especially in the northern aspects where expandable clay minerals such as smectite and vermiculite are dominant [8]. In these areas, crack formation plays as the inlet for water entering and soil layers and consequently landslide occurrence. Sliding in the marls was initiated near the highest parts of main scarp (crown cracks) where water and run-off absorbed by cracks during 
rainfall in the smectitic and vermiculitic soils [9].

The non-phyllosilicate soils contained expandable mineral such as calcite, dolomite and feldspar are other common minerals in the semi-arid region. In this region, unlike smectite and vermiculite, they do not contribute to piping, gully and sliding phenomena. The surface charges of these mineral are close to zero, resulting a soil with intermediate aggregate stability and also contributing to the intermediate soil losses [10]. Illite, kaolinite, quartz and feldspar are also other minerals in the soil and rock in the semi-arid region affecting soil erosion features due to their specific properties. Low crystalline illite, kaolinite, fine quartz and feldspar in the sedimentary rocks are found in these areas [11]. This area of Iran occurrence of kaolinite, illite and chlorite in the soil is due to their origin from the surrounding Cretaceous parent rocks [7]. Mudstone is the common intermediate among sedimentary rocks in most parts of Iran, especially in Zagros Mountain and induces a soil with low porosity, high run-off potential and erosion hazard. These properties reflect a warm environmental formation which was characterized by the shallow depths $(<2.0 \mathrm{~km})$ under high temperature and mechanical pressure resulting in progressive alteration of illite and smectite, isolation of quartz in silt and release of silica into solution [12]. The objectives of this study were: 1) to identify the dominant soil and rock minerals; and 2) examine the influences of mineralogical properties on occurrence of soil erosion.

\section{Materials and Methods}

\subsection{The Study Area}

This study was conducted at the Merek watershed, located about $35 \mathrm{~km}$ southeast of Kermanshah, Iran. It is the upper catchment of the Karkheh river basin (KRB) located in Zagros Mountain chains (west of Iran) (Figure 1). Merek watershed has an area of 23,038 ha that lie between $34^{\circ} 00^{\prime} 38^{\prime \prime}$ to $34^{\circ} 09^{\prime} 31^{\prime \prime} \mathrm{N}$ and $47^{\circ} 04^{\prime} 25^{\prime \prime}$ to $47^{\circ} 22^{\prime} 18^{\prime \prime}$ (UTM 1984; zone $38 \mathrm{~N}$ ). The minimum and maximum elevations above sea level are 1440 and 2820 $\mathrm{m}$, respectively. The geological formation of this watershed comprises plains, hilly and mountainous areas with forest, rangeland and agricultural land-use. The mean annual precipitation and temperature are $470 \mathrm{~mm}$ and $7.6^{\circ} \mathrm{C}$, respectively indicating the Warm Mediterranean climatic type in accordance with Coppen classification.

Land degradation in this catchment is accelerated (particularly gully and landslide) by deforestation, overgrazing and improper tillage activities. Agriculture, rangeland and forest with the respective area of 14,810, 6632 and 1596 ha are the main land-use types. Rangeland and forest are more sensitive to soil erosion due to topography and geological properties. In this study, a geomorpholo-

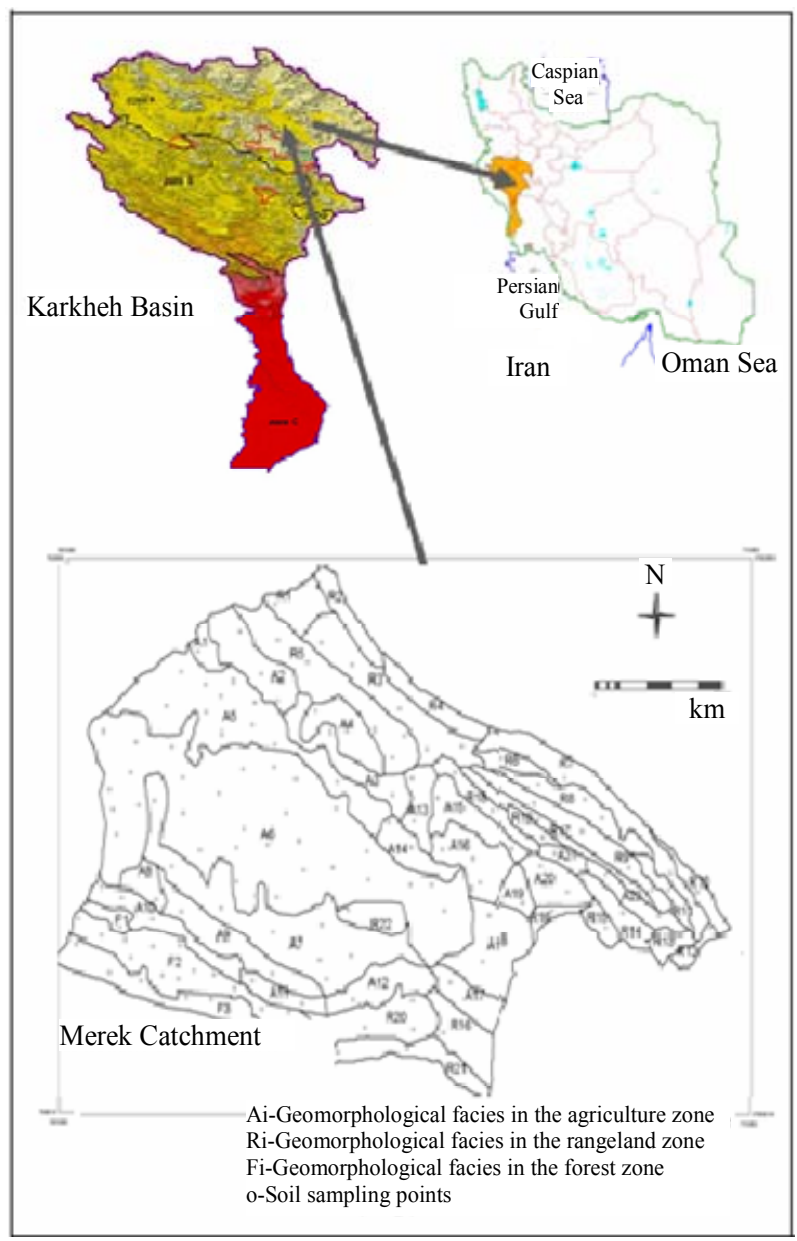

Figure 1. A map showing the location of the Merek watershed.

gical facies map as the homogenous area was prepared by overlapping the maps of geology, topography (slope steepness, elevation), erosion features and land use type.

\subsection{Geology and Erosion Maps}

The geological formation was mapped based on geology quadrangle map of Kermanshah (on a scale of 1:100,000) which has been prepared by the Geological Survey of Iran (GSI). The border of each geological formation was checked in the field, using GPS and digitized by GIS software (ILWIS 3.5). The erosion feature map was prepared through remotely sensed data (Landsat ETM+ 2002, UTM; WGS 84; zone 38N). Image interpretation was carried out visually and digitally. The best bands to create the image with maximum useful information in color composition processing were selected by optimum index factor (OIF) for erosion features and vegetation cover (band 7 and 5 for erosion feature and vegetation cover, respectively with $30 \mathrm{~m}$ resolution). The border of each main erosion features including inter-rill, rill, gully and river bank were verified the field. Soil erosion inten- 
sity was estimated using the Modified Pacific Southwest Inter-Agency Committee (MPSIAC) model [13]. This model is more suitable for semiarid region because it comprises of nine factors of geology, soil ( $\mathrm{K}$ factor of RUSEL), climate, runoff, topography, ground cover, land use, surface erosion and gully erosion [13].

\subsection{Soil Sampling and Analyses}

Soil samples were collected from depths of $0-20 \mathrm{~cm}$ within each geomorphological facies (homogenous areas within watershed in terms of geology, slope, land-use and erosion features which prepared by GIS) followed by stratified random soil sampling and their coordinates were determined by GPS. The dried soil samples were sieved through $2 \mathrm{~mm}$ mesh sieve. Soil physico-chemical characteristics were determined in the laboratory. The particle size distribution and soil texture were determined by the pipette method [14]. The $\mathrm{pH}$ of the saturated soil paste was measured by a $\mathrm{pH}$ meter. Organic carbon was determined by the Walkley and Black method [15]. The carbonate in the soils was measured by the titration method using sodium hydroxide solution and organic carbon was determined by the Walkley and Black method [15].

\subsection{Soil and Rock Mineralogy}

Soil and rock mineralogy were analyzed for sand, silt, clay and rock fractions [16]. The calcium carbonate in the sample was removed by hydrochloric acid and clay particles were separated using centrifuge at $800 \mathrm{rpm}$ for the 3 minutes. Organic carbon was removed by $10 \mathrm{ml}$ of $\mathrm{H}_{2} \mathrm{O}_{2}$ using centrifuge (for $15 \mathrm{~min}$ at $1500 \mathrm{rpm}$ ). About half of clay fraction was saturated with $3 \mathrm{ml}$ of $1 \mathrm{M} \mathrm{KCl}$ and the remaining was saturated with $\mathrm{MgCl}_{2}$. Sand, silt and rock particles were grinded manually by agate mortar using some drops of distilled water until all particles well homogenized as a powder. The orientated glass specimens were prepared for Mg-clay, K-clay, silt, sand and rock particles and allowed air-dried. The XRD of specimens were run by diffractometer (Phillips Analytical X-ray; X'pert model) using X-ray powder diffraction method and diffractograms of slides were printed. The $\mathrm{Mg}$-clay specimens were treated with ethylene glycol and heated at $55^{\circ} \mathrm{C}$ for distinguishing smectite from vermiculite and were scanned slowly $\left(0.5^{\circ} / \mathrm{min}\right)$ again by XRD.

\section{Results and Discussion}

\subsection{Geological Formation}

Merek watershed is located in the folded belt zone of Zagros chain (west and SW of Iran). It is a branch of the Alpine-Himalayan belt comprising a sequence of Precambrian to Pliocene shelf sediments which have been folded into a series of huge anticline mountain and syncline valley. The drainage patterns and topographic dips have been formatted by local folded and faults. There are different sedimentary rocks mainly limestone, sandstone, radiolarite, flysch, shale and marl. Table 1 shows the main characteristics of geological formations in the study area as follows (Figure 2 and Table 1).

Table 1. Lithological properties of geologic formations in the Merek watershed*.

\begin{tabular}{|c|c|c|c|c|c|c|}
\hline \multirow{2}{*}{ Era } & \multirow{2}{*}{ Period } & \multirow{2}{*}{ Age } & \multirow{2}{*}{ Formation } & \multicolumn{2}{|c|}{ Area } & \multirow{2}{*}{ Main lithology properties } \\
\hline & & & & ha & $\%$ & \\
\hline \multirow{4}{*}{ Cenozoic } & \multirow{2}{*}{ Quaternary } & & Younger terraces & 8330.10 & 36.18 & Deposits of marl, argillaceous, sand and silt \\
\hline & & Pleistocene & Older terraces & 3430.45 & 14.89 & $\begin{array}{l}\text { Deposits of marl, argillaceous, sand and silt } \\
\text { with middle layers of gravel, conglomerate, } \\
\text { and limestone }\end{array}$ \\
\hline & \multirow{5}{*}{ Cretaceous } & \multirow{2}{*}{ Eocene } & Shahbazan & 812.40 & 3.54 & $\begin{array}{l}\text { Dolomite and limestone with high pores, } \\
\text { and without fossil }\end{array}$ \\
\hline & & & Kashcan & 2807.13 & 12.16 & $\begin{array}{l}\text { Claystone, siltstone, and sandstone with } \\
\text { middle layer of conglomerate, }\end{array}$ \\
\hline \multirow{3}{*}{ Mesozoic } & & & Gurpi & 2835.40 & 12.29 & $\begin{array}{l}\text { Shale, marlstone with middle layer of } \\
\text { argillaceous, and fine limestone }\end{array}$ \\
\hline & & Upper cretaceous & Ilam & 2656.50 & 11.52 & $\begin{array}{l}\text { Limestone with middle layer of argillaceous, } \\
\text { shale, and conglomerate }\end{array}$ \\
\hline & & Lower cretaceous & Sarvak & 1351.40 & 5.87 & $\begin{array}{l}\text { Limestone and dolomite with thin interlayer } \\
\text { of argillaceous }\end{array}$ \\
\hline Total & & & & 23038.13 & 100 & - \\
\hline
\end{tabular}

*Based on geology map of Kermanshah (Karimibavandpoor et al., 1999). 


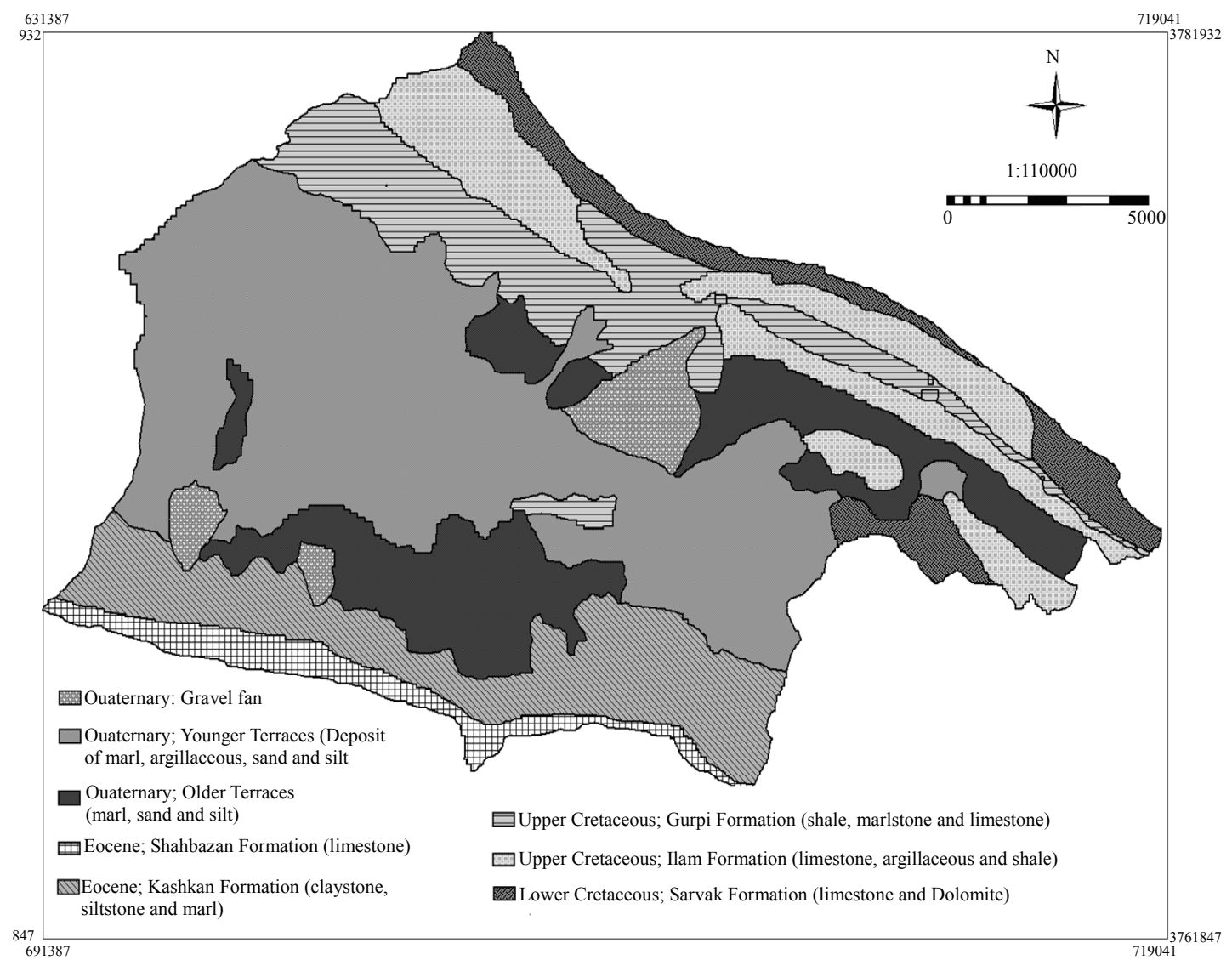

Figure 2. The geological formations in the Merek watershed.

\subsubsection{Sarvak Formation}

Sarvak Formation is the oldest geological formation that include lower, middle and upper layer of limestone and dolomite with interlayer of argillaceous in upper layer. Identification of the exact boundary between the Ilam and Sarvak Formations is difficult because of their almost similar lithological composition [17]. This formation occupies mountainous area (about $6 \%$ of the study area) and characterized by debris, local cliff, and frequent joints in rock outcrops. Snow and frost-towing are tow agents affecting debris formation, especially accumulation of fragmented rocks in down parts.

\subsubsection{Ilam Formation}

Ilam Formation has been separated from Sarvak Formation gradually with conformity dip. This formation includes dark and light limestone, thin to medium middle layer of argillaceous, shale and conglomerate. Field observations showed that rill, inter-rill and shallow landslides are main erosion features at this formation occupying 2656 ha (11.5\%) of the Merek watershed.

\subsubsection{Gurpi Formation}

Gurpi Formation includes shale, marl, and pelagic limestone that are fine and regular grain (Campaine-Maes).
This formation covers the Ilam Formation conformity and particles size increase from bottom to the upper layers. It has been formed in an open and relatively deep marine environment [18].

\subsubsection{Kashkan Formation}

Kashkan Formation has been covered Gurpi Formation by conformity dip and in the Merek watershed shows the presence of reddish claystone, siltstone and sandstone, inter-layered with conglomerate and limestone. Field observations showed the outcrops of limestone and conglomerate, which were shallower than the other layers and claystone was more frequent in the field (old Paleocene-middle Eocene). It is hilly areas and is covered by forest and landslide is dominant degradation form because of its unique geological and topographical properties. About $12 \%$ of study area (mainly south part) is covered by this formation (Table 1).

\subsubsection{Shahbazan Formation}

Shahbazan Formation is characterized by ticket layers of dolomite and limestone with medium to coarse grains and pores. The geological age of this formation is equal Kashkan Formation (old Paleocene-middle Eocene). There are verity of erosion features mainly inter-rill, rill 
and limited rocks slides at this formation.

\subsubsection{Quaternary Deposits}

Quaternary Deposits includes; Pleistocene and Holocene with 1.9 millions year age. The main area of Merek watershed $(\sim 55 \%)$ is occupied by Quaternary deposits, on old and young terraces $(\mathrm{Qt})$, and alluvium fans (Qf)

A) Terraces $(\mathbf{Q t})$ : The terraces composites of older and younger terraces of river and main valleys of Merek syncline. There are marl, argillaceous, sand and silt deposits with middle layers of gravel, conglomerate and limestone. The origins of these terraces are adjacent geological formations (mainly marl formations), radiolarite-ophiolite trusted and flysch (tertiary period). The older terrace is located in southern side of Merek and specified on geological formation map by Qt1 symbol. The younger terraces occupied most of the Merek plain (agriculture area) and specified on geological formation map by Qc symbol.

B) Gravel fans (QF): Gravel fans include mountain flooded force between mountain and plain. There are two main alluvial fan in Merek watershed; one in the north of Najaf-e-Abad village, and upside of terraces in south part of Merek. The deposit of these areas are coarser than terraces and including; gravel, sand, with middle layers of clay, and silt.

\subsection{Dominant Soil Erosion Features}

In the study area, there are four main erosion features
(Table 2 and Figure 3). Gully and rill erosion are dominant in the agricultural lands, whereas landslide occurs frequently in the forest which is dominated by marl and shale. The main characteristics of each erosion feature are subsequently explained as follows.

\subsubsection{Inter-Rill, Rill and Snow Erosion}

It was observed that about $43.56 \%$ (10053.90 ha) of the study area were affected by a mixed erosion features including inter-rill, rill and snow erosions. However, inter-rill erosion occurs when surface soil particles are detached via raindrops and frost actions. There was easily visible in the field and also easily distinguished from satellite images. The affected areas by rill erosion were observed where plant cover was destroyed or decreased by grazing, tillage practice and fire at the slope of $10 \%$ $20 \%$ during crop cultivation, which takes place in early October to November. Rill erosion is the most common

Table 2. Erosion features in the Merek watershed.

\begin{tabular}{ccc}
\hline \multirow{2}{*}{ Erosion features } & \multicolumn{2}{c}{ Area } \\
\cline { 2 - 3 } & ha & $\%$ \\
\hline Inter-rill, rill and snow erosion & 10053.90 & 43.56 \\
Gully erosion & 3495.05 & 15.27 \\
Miscellaneous gully-bank erosion & 5870.80 & 25.47 \\
Landslide-rill erosion & 3618.38 & 15.70 \\
Total & 23038.13 & 100 \\
\hline
\end{tabular}

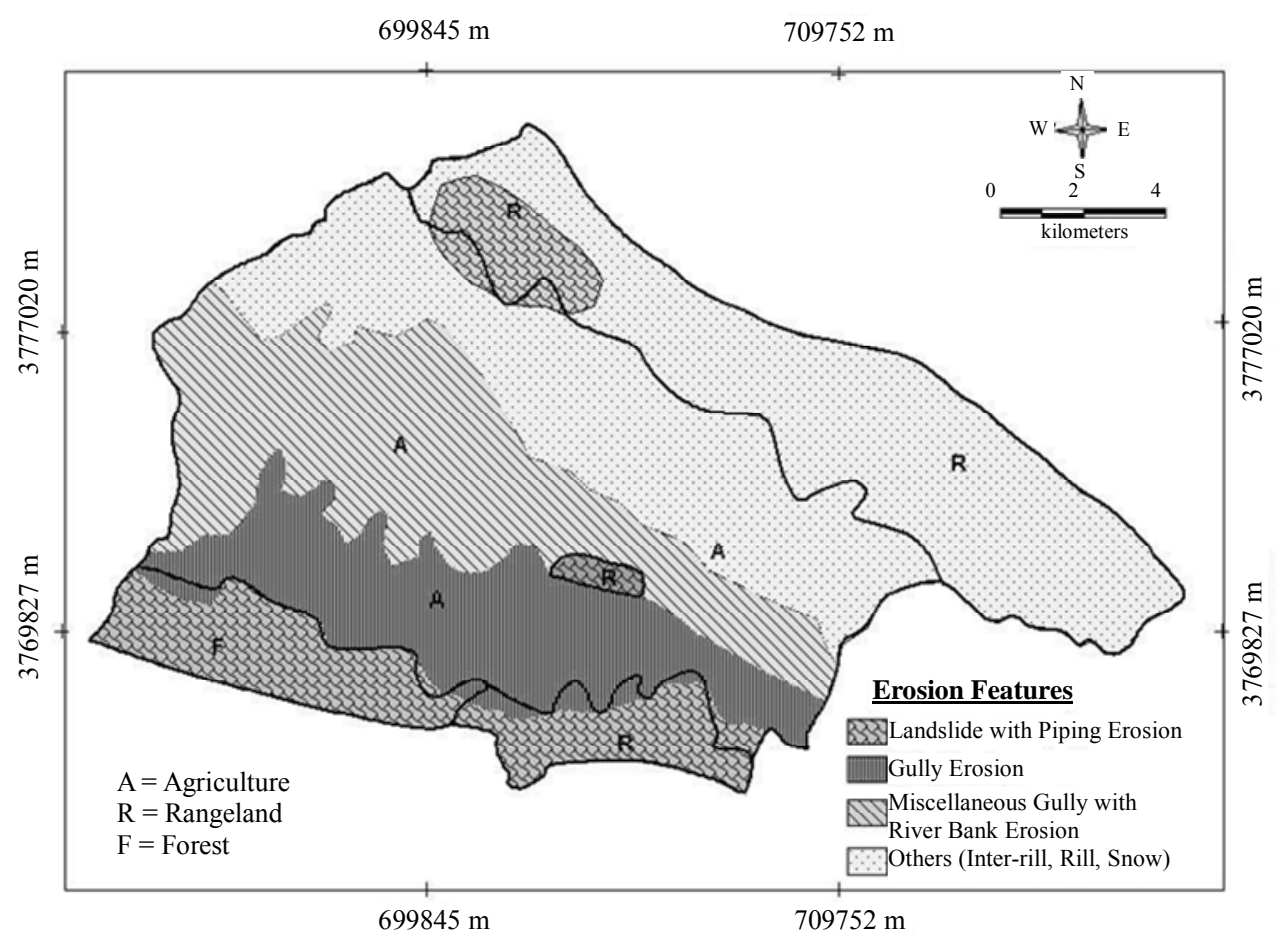

Figure 3. Spatial distribution of dominant erosion features in the Merek watershed. 
type of erosion occurring on bare land, promoted mostly by surface run-off where overland flow becomes channeled and sheer stress (by overland flows) is more than shear strength of the soils $[19,20]$.

Snow erosion with debris dominated in the north and northeast of the study area (mainly at the Sarvak Formation) and is characterized by high elevation, cliffs, rock outcrops and steep sloped. Water from the melted snow (end of March until early April) moved down slope soil, gravel and fragmented rocks.

\subsubsection{Gully Erosion}

About $15 \%$ of the study area is influenced by gully erosion including rain-fed and irrigation framings which geologically are susceptible to degradation. Gully development is triggered by anthropogenic factors such as improper agricultural activities, vegetation clearance, irrigation systems, overgrazing and road building. These activates resulted in run-off concentration and consequently fluvial incision of gully [21-23]. Gully erosion affects depositions of marl, shale and sandstone (Older Terraces) which mainly originated from the Kashkan Formation. Field survey showed that heavy tillage without fallow and rotations periods have led to the development of V-shaped gullies alongside farm and village roads. Furthermore, the head-cuts of gullies follow tillage direction and furrows in the rain-fed and irrigated farms, respectively. The upwards of gully (head-cut) is initiated by crack formation in the fine grained layers containing vermiculite and mica/smectite. The cracks were found in different sizes $(1-10 \mathrm{~cm})$. There are visible before elimination by livestock traffic or agricultural activities. Soils in these areas are clayey in nature with low organic carbon (about 1\%). The sequence of the gully phenomenon can be summarized as follows:

$$
\text { Crack } \rightarrow \text { Head-Cut } \rightarrow \text { Gully Development. }
$$

\subsubsection{Miscellaneous Gully-Bank Erosion}

Miscellaneous gully and river bank erosion influence $25.47 \%$ of the study area (Table 2 ). It is a common erosion feature on the gentle slopes $(\sim 2 \%)$ and Quaternary deposits (younger terraces). Gullies were found deeper and miscellaneous around the river, but river bank erosion is occurs in the meanders and conjunction of river branches. The mineralogy of these areas is similar to gully erosion area.

\subsubsection{Landslide-Piping Erosion}

Piping (tunneling) erosion is common in the arid and semi-arid regions that change the geomorphic and hydrologic characteristics of affected areas [19]. Most of the landslides occurring in Merek watershed are initiated by piping and cracking. It was observed that most of the landslide occurs at Kashkan Formation with high elevation, relatively steep slope $(\sim 30 \%)$ and northern aspect. Soils in this area can maintain more moisture due to the low evaporation [24]. This condition can provide water for the expansion of smectite, which is a dominant soil mineral. Landslide in Iran occurred frequently where the slope was $20 \%$ - 40\% [25]. Field observations in the Merek watershed showed that piping and landslides occurred frequently in the recently cleared forest, which enhance soil erosion. About 16\% (3618 ha) of the study area is affected by landslide-piping (Table 2). This piping is formed upwards as a result of crack formation. The sequence of the landslide phenomenon can be summarized as follows:

$$
\text { Crack } \rightarrow \text { Piping } \rightarrow \text { Landsides. }
$$

\subsection{Contribution of Mineralogy on Soil Erosion}

\subsubsection{Snow, Inter-Rill and Rill Erosion}

Snow, inter-rill and rill erosion features occurred at the Sarvak, Illam and Gurgi Formations. As shown in Table 3 and Figure 4, the presence of peaks at $3.04 \AA, 4.24 \AA$ and $2.90 \AA$, indicating the presence of calcite, quartz and dolomite, respectively, in the limestone of Sarvak (a), Gurpi (b) and Ilam (c) Formations. This result shows that although almost slope of these formations are high (mainly $>40 \%$ ), it is not subjected to severe erosion due to high carbonate content. Moderate annual rainfall (more than $450 \mathrm{~mm}$ ) promotes carbonate accumulation and consequently high pores and joints formation resulting in high runoff penetration. Soil carbonates originate from several sources or combination of sources, either directly in the parent material or by solution precipitation mechanism such as dissolution of Ca-bearing mineral, mineralization and rainwater [26].

Soil minerals from Sarvak and Gurpi also include calcite and quartz, but kaolinite and vermiculite are minimal in the soil indicating lower soil erosion potential. Soil physico-chemical analysis also revealed that sand proportion of soil from these areas is relatively high ( $20 \%)$ indicating resistance against detachment process. Soil organic carbon (SOC) except at Sarvak (0.5\% SOC level due to limited vegetation cover) was roughly as same as most parts of the study areas (Table 4). The respective soil erosion intensity from soil at Sarvak, Ilam ansd Gurpi was 5.12, 10.40 and $8.85 \mathrm{t} \cdot \mathrm{ha}^{-1} \cdot \mathrm{yr}^{-1}$ indicating low to moderate erosion hazard. As shown in Table 3 and Figure 4(d), the relative higher erosion potential mainly from Illam is related to high clay content and dominant vermiculite. Soil carbonate in this area is high curtailing soil erosion hazard. Pedogenic carbonates are aggregate of silt-sized calcite crystal and its sand-size crystals are inherited from soil parent material [24]. Although soil kaolinitic is minor, it can affect soil aggregation. The soil 
Table 3. Mineralogical data of the parent materials and soils in the Merek watershed.

\begin{tabular}{|c|c|c|c|c|c|c|c|c|c|}
\hline \multirow{2}{*}{ Dominant Erosion and Land Use } & \multirow{2}{*}{ Geological Formation } & \multirow{2}{*}{ Fractions } & \multicolumn{7}{|c|}{ Minerals* } \\
\hline & & & $\mathbf{Q}$ & $\mathrm{C}$ & Mi & D & $\mathbf{V}$ & $\mathbf{K}$ & $\mathrm{S}$ \\
\hline \multirow{4}{*}{$\begin{array}{l}\text { Snow erosion and debris with rill and } \\
\text { inter-rill rangeland and rock outcrops }\end{array}$} & \multirow{4}{*}{ Upper Cretaceous (Sarva For.) } & Rock & ++ & +++ & - & ++ & - & $\operatorname{tr}$ & - \\
\hline & & Sand & + & +++ & - & + & - & - & - \\
\hline & & Silt & ++ & +++ & - & - & $\operatorname{tr}$ & + & - \\
\hline & & Clay & ++ & +++ & - & - & $\operatorname{tr}$ & + & - \\
\hline \multirow{4}{*}{$\begin{array}{l}\text { Rill and inter-rill erosion rain-fed } \\
\text { agriculture and rangeland }\end{array}$} & \multirow{4}{*}{ Upper Cretaceous (Gurpi For.) } & Rock & & & & ++ & & & \\
\hline & & Sand & +++ & ++ & - & $\operatorname{tr}$ & - & - & - \\
\hline & & Silt & +++ & ++ & - & - & - & - & - \\
\hline & & Clay & ++ & $\operatorname{tr}$ & + & - & + & + & + \\
\hline \multirow{4}{*}{$\begin{array}{l}\text { Rill and inter-rill erosion rain-fed } \\
\text { agriculture and rangeland }\end{array}$} & \multirow{4}{*}{ Upper Cretaceous (Ilam For.) } & Rock & ++ & +++ & - & + & $\operatorname{tr}$ & + & - \\
\hline & & Sand & +++ & ++ & + & - & - & - & - \\
\hline & & Silt & ++ & +++ & - & - & + & $\operatorname{tr}$ & - \\
\hline & & Clay & ++ & ++ & - & - & +++ & ++ & - \\
\hline \multirow{4}{*}{$\begin{array}{l}\text { Gully erosion irrigated and rain-fed } \\
\text { agriculture }\end{array}$} & \multirow{4}{*}{ Older Terraces } & Rock & +++ & ++ & ++ & + & - & $\operatorname{tr}$ & - \\
\hline & & Sand & ++ & +++ & $\operatorname{tr}$ & + & - & + & - \\
\hline & & Silt & +++ & ++ & $\operatorname{tr}$ & + & + & ++ & - \\
\hline & & Clay & ++ & ++ & - & + & +++ & ++ & ++ \\
\hline \multirow{4}{*}{ Landslide forest (mainly) and rangeland } & \multirow{4}{*}{ Eocene (Kashkan For.) } & Rock & + & ++ & $\operatorname{tr}$ & - & - & + & +++ \\
\hline & & Sand & +++ & ++ & - & + & - & - & - \\
\hline & & Silt & ++ & +++ & + & + & $\operatorname{tr}$ & + & + \\
\hline & & Clay & + & - & - & $\operatorname{tr}$ & - & ++ & +++ \\
\hline
\end{tabular}
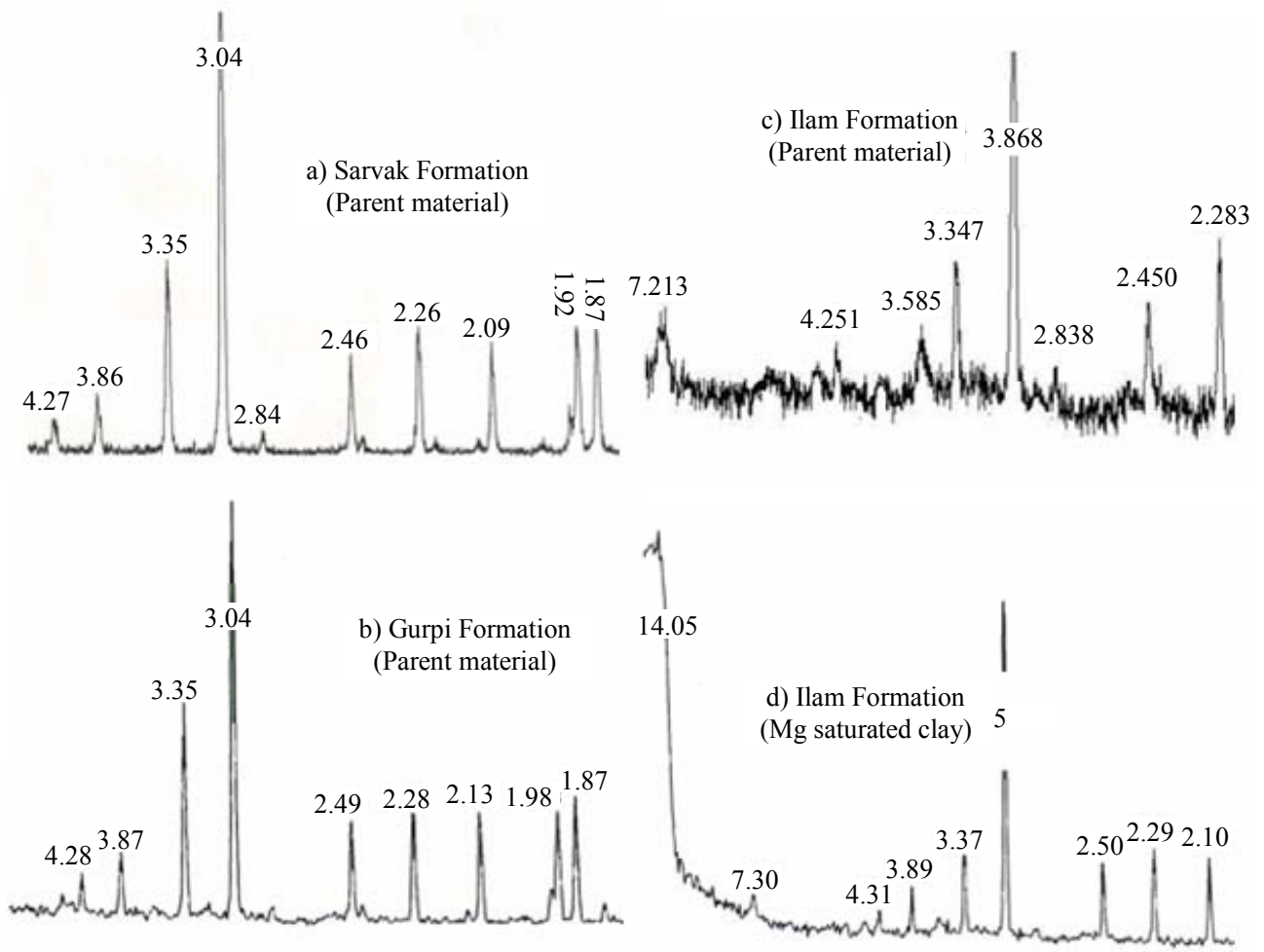

Figure 4. X-ray diffraction patterns of parent materials of Sarvak (a), Gurpi (b) and Ilam (c) and soil (d) clay particle of Ilam Formationd under debris, rill, inter-rill and snow erosion. 
loss from the kaolinitic soil is the lowest because the aggregate stability of this soil is the highest which decreased soil detachment, and because the runoff rate obtained during the rainstorm in this soil was the lowest [10].

\subsubsection{Gully Erosion}

There are various types of minerals present in both the parent materials and soils of the older terraces, where most of the gullies occur. The X-Ray Diffraction (XRD) pattern in Figure 5 shows the presence of peaks at 3.301 $\AA, 3.030 \AA, 10.710 \AA$ and $2.104 \AA$ indicating the presence of quartz, calcite, mica and dolomite, respectively. As shown in Table 3, the dominant, common, minor and trace minerals in the sand fractions include calcite, quartz, dolomite and mica, respectively, whereas silt fractions comprise quartz and calcite, dolomite, kaolonite and mica. The clay specimens were treated with $\mathrm{K}, \mathrm{Mg}$ and Mg-glycol and the three diffractograms were superimposed. The $\mathrm{K}, \mathrm{Mg}$ and $\mathrm{Mg}$-treated sample show the peaks at $14.040 \AA, 13.950 \AA$ and $14.280 \AA$, indicating the presence of vermiculite at the $\sim 6.5^{\circ}\left(2^{\circ}\right.$ Theta), but there was

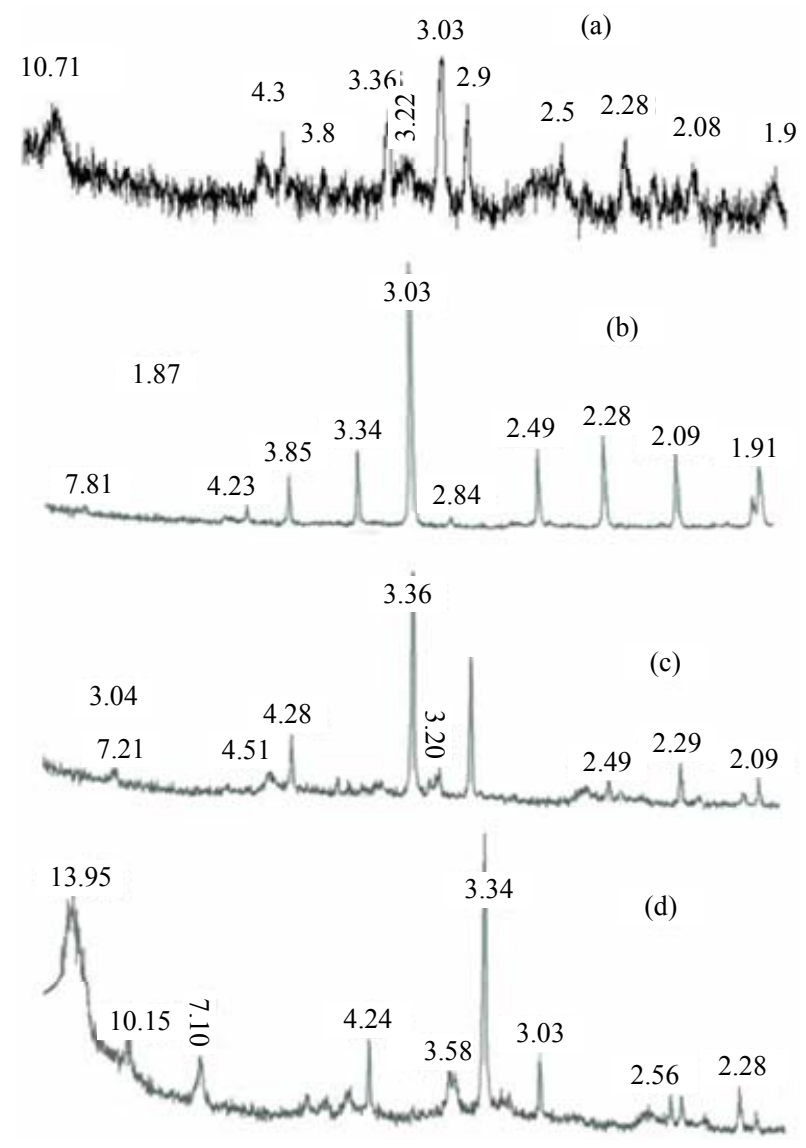

Figure 5. X-ray diffraction patterns of the parent material and soil in the gully erosion areas: (a) Parent material (older terraces); (b) Sand fraction (soil); (c) Silt fraction; and (d) Clay fraction.
$12.060 \AA(\mathrm{K}), 9.960 \AA(\mathrm{Mg})$ and $10.140 \AA$ (Mg-glycol) indicating the presence of mica/smectite at the $\sim 8.8 \AA$.

Soils in this area contain $46 \%$ clay and low of SOC $(1.15 \%)$ which potentially contribute to development of gully erosion. This high clay content resulted considerable action of mica/smectite in gully formation which is initiated by swell/crack process trough concentrated runoff during rainfall season resulting in crack formation. The low SOC is related to improper agricultural activities mainly crop residue burning, accelerate crack formation as the first step of gully erosion.

\subsubsection{Landslides Occurrence}

As shown in Figure 6, Kashkan Formation is wholly subjected to landslide incidence. Furthermore, Shabazan and Ilam are partly affected by shallow surface sliding phenomenon. The X-Ray Diffraction (XRD) pattern in Figure 6(a) shows the presence of peaks at $14.75 \AA, 7.24$ $\AA, 4.56 \AA, 3.02 \AA$ and $2.87 \AA$ indicating the presence of smectite, kaolinite, quartz, calcite and dolomite, respectively in the parent material of Kashkan Formation. XRD diffractogram of the clay fraction of the soil developed from this formation is also given in Figure 6(b). The sample was treated with $\mathrm{Mg}, \mathrm{Mg}$-glycol and $\mathrm{K}$ and their diffractograms were superimposed. The Mg-treated sample shows a peak at $14.881 \AA$, indicating the presence of

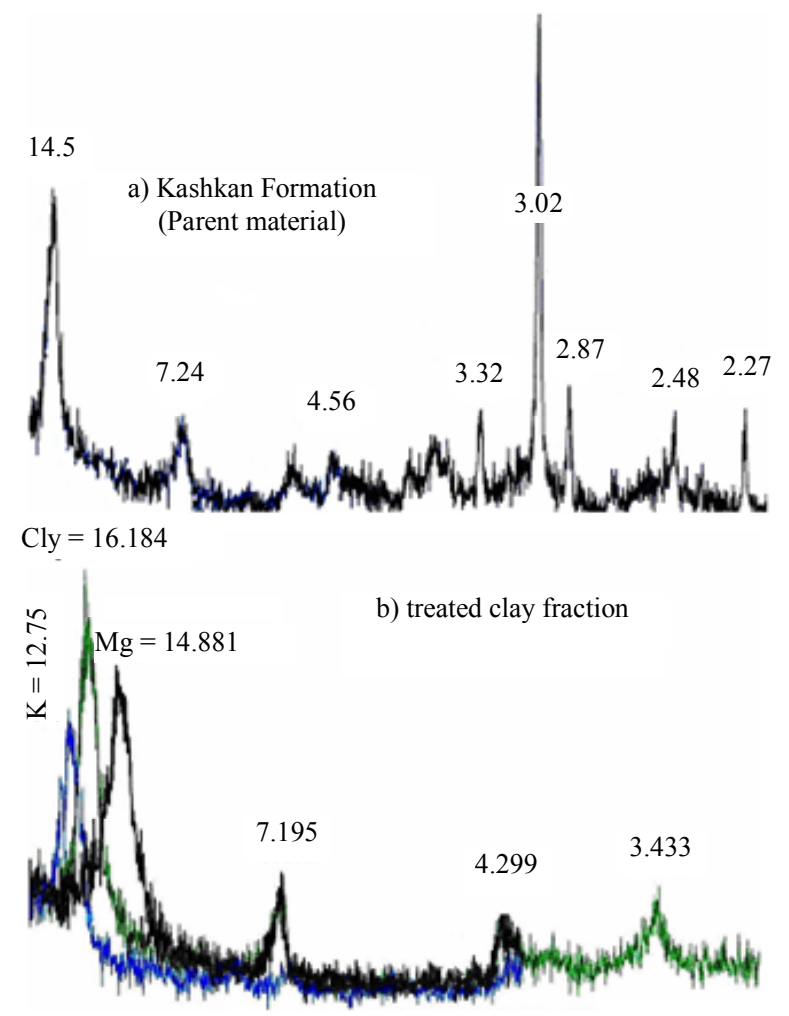

Figure 6. (a) X-ray diffractogram of the Kashkan Formation parent material; (b) Treated clay fraction with $\mathrm{Mg}$, glycol and $\mathrm{K}$; the diffractograms are superimposed. 
Table 4. Dominant rock and soil minerals, soil properties and soil erosion at the geological formations in the in the Merek watershed.

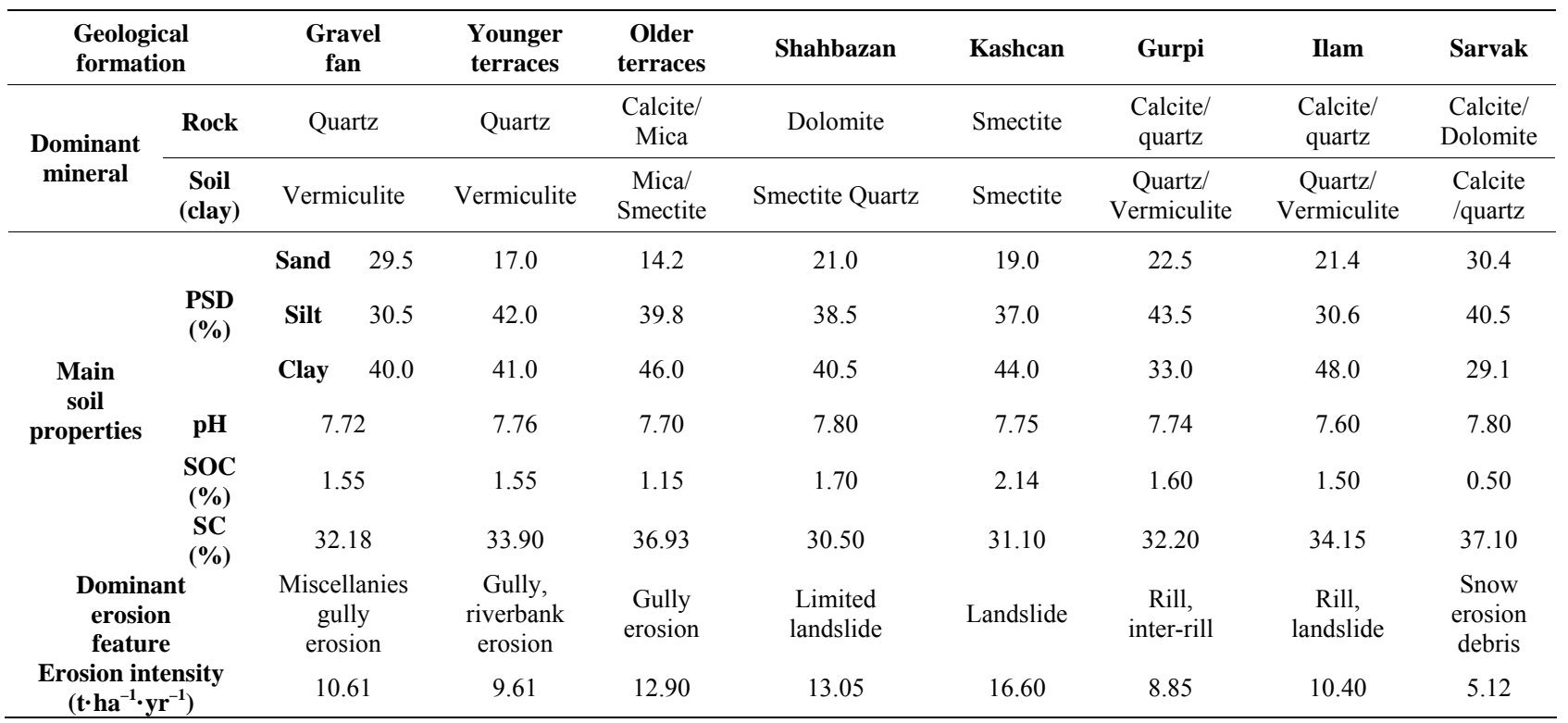

$\mathrm{PSD}=$ Particles Size Distribution, $\mathrm{SOC}=$ Soil Organic Carbon, $\mathrm{SC}=$ Soil Carbonate.

smectite, vermiculite, chlorite or all of them. Glycolating the Mg-saturated sample produced a peak at $16.184 \AA$. This result shows clearly the presence of smectite in the sample. K treatment gave a peak at $12.755 \AA$; peak at 14 $\AA$ peak was absent. This shows chlorite is absent in the soil.

These results imply that quartz and calcite are the dominant minerals in soil from Kashkan while mica, vermiculite and kaolinite are present in trace amounts in the coarse fraction of the soils (Table 3). Smectite is the dominant mineral in both parent material and fine fraction of the soils under landslide occurrence. Smectite affects soil infiltration rate through sealing formation in the soil surface. In the smectite soils with low level of organic matter content, raindrop contribute to soil aggregates dispersion and smooth seal development [10]. In this process, the dispersed clay particles, transferred from the upper layer with the infiltrated water resulting in crust formation. However, the high clay content (44\%) in this area resulted in high water absorption giving soil with high potential of sliding hazard. Although the SOC in this areas was found relatively moderate value $(2.14 \%$ at the surface soil), it is influenced mainly by local inhabitants activities such as forest clearance and livestock grazing. Soil erosion intensity from this area was estimated $16.60 \mathrm{t} \cdot \mathrm{ha}^{-1} \cdot \mathrm{yr}^{-1}$ Table 4). In the some protected areas of forest SOC was about $3 \%$ and sliding sites was significantly less that affected area.

\section{Conclusion}

In the Merek watershed, soil erosion is an extensive land degradation phenomenon, especially within the forest and rangeland areas. Although this area geologically and topographically is prone to gully, inter-rill and landslide occurrence, it is enhanced by improper agricultural activities, forest clearance and overgrazing. The erosion features are affected by both soil and rock mineralogy. Carbonate (Calcite and dolomite) and quartz contribute to soil aggregation and consequently resistance against soil particle detachment. Sarvak, Gurpi had found two formations dominated by these minerals giving soil with inter-rill, rill and snow erosion features and relatively lower erosion intensity. In contrast, Kashkan dominates a soil with smectite and high clay content resulting in landslide occurrence with high soil erosion intensity. The mineralogy of gully erosion is dominated by mica/smectite (at the Older Terraces) which almost originated from Kashkan Formation following landslide phenomenon, but in the gentle slope. Both gully and landslide are accelerated by improper agricultural activities, deforestation and livestock grazing in the Merek watershed, Iran.

\section{Acknowledgements}

The authors would like to acknowledge Agriculture and Natural Research Center of Kermanshah, Iran and Universiti Putra Malaysia (UPM), for financial and technical support.

\section{REFERENCES}

[1] S. T. Frydman, M. Talesnick, S. Geffen and A. Shvarzman, "Landslides and Residual Strength in Marls Profiles 
in Israel," Engineering Geology, Vol. 89, No. 1-2, 2007, pp. 36-46. doi:10.1016/j.enggeo.2006.09.009

[2] E. Istanblluoglu, R. L. Bras and H. F. Cervantes, "Implication of Bank Failures and Fluvial Erosion for Gully Development: Field Observations and Modeling," Journal of Geophysical Research: Earth Surface, Vol. 110, No. F1, 2005, pp. 50-70.

[3] H. R. Owliaie, A. Abtahi and R. J. Heckr, "Pedogenesis and Clay Mineralogical Investigation of Soils Formed on Gypsiferous and Calcareous Materials, on a Transect, Southwestern Iran," Geoderma, Vol. 134, No. 1-2, 2006, pp. 62-81. doi:10.1016/j.geoderma.2005.08.015

[4] A. J. Lutengger and A. J. Cerato, "Surface Area and Engineering Properties of Fine-grained Soil," University of Massachusetts Press, Amherst, 2008.

[5] J. Krenz, B. Lee and P. Owens, "Swelling Clays and Septic Systems: High Water Tables and Septic System Perimeter Drains," Department of Agriculture (USDA), USA, 2000. www.ces.purdue.edu/extmedia.

[6] G. Borchardt, "Smectites," In: J. M. Bighman, J. B. Dixon, M. H. Milford, C. B. Roth and S. B. Weed, Eds., Minerals in Soil Environments, American Society for Agronomy and the Soil Science Society of America, Madison, Washington, 1989, pp. 728-767.

[7] F. Khomali and A. Abtahi, "Distribution of Clay Minerals in Calcareous Arid and Semi-Arid Soils of Fars Province, Southern Iran," Clay Minerals, Vol. 38, No. 4, 2003, pp. 511-527.

[8] H. Ahmadi and A. T. Esfandarani, "Study of Effective Factors on Mass Movements (Landslide); Case Study: Ardal Region of Chaharmahale Bakhtiari Province, Iran," Natural Resources (Iran), Vol. 54, No. 4, 2002, pp. 323329.

[9] F. G. C. Cakoglu and M. Ercanoglu, "Dynamics of a Complex Mass Movement Triggered by Heavy Rainfall," Journal of Geomorphology (Turkey), Vol. 42, No. 3-4, 2002, pp. 329-341. doi:10.1016/S0169-555X(01)00094-0

[10] M. Lado and M. Ben-Hur, "Soil Mineralogy Effects on Seal Formation, Runoff and Soil Loss," Applied Clay Science, Vol. 24, No. 3-4, 2004, pp. 209-224. doi:10.1016/j.clay.2003.03.002

[11] H. M. Baioumy and H. M. Gharaie, "Characterization and Origin of Late Devonian Illity Clay Deposit Southwestern, Iran," Applied Clay Science, Vol. 42, No. 1-2, 2008, pp. 318-325. doi:10.1016/j.clay.2007.12.003

[12] C. Peltonen, K. M. Bjorlykke and J. Jahren, "Clay Mineral Diagenesis and Quartz Cementation in Mudstones: The Effects of Smectite to Illite Reaction on Rock Properties," The Journal of Geology, Vol. 26, No. 6, 2009, pp. 887-898.

[13] R. Safamanesh, W. N. Azmin-Sulaiman and F. M. Ramli, "Erosion Risk Assessment Using an Empirical Model of Pacific South West Inter-Agency Committee Method for
Zardeh Watershed, Iran," Journal of Spatial Hydrology, Vol. 1, 2006, pp. 105-120.

[14] C. B. S. The and J. Talib, "Soil Physics Analyses," Universiti Putra Malaysia Press, Serdang, 2006.

[15] R. E. Nelson and L. E. Sommers, "Total Carbon, Organic Carbon and Organic Matter," In: D. R. Keeney, D. E. Baker, R. H. Miller, R. J. Ellis and J. D. Rhoades, Eds., Methods of Soil Analysis, Part 2. Chemical and Microbiological Properties. American Society for Agronomy and the Soil Science Society of America, Madison, Wisconsin, 1982, pp. 539-580.

[16] S. Whitton and G. J. Churchman, "Standard Methods for Mineral Analyses of Soil Survey Samples for Characterization and Classification in New Zealand Soil Bureau," NZ Soil Bureau, Scientific Report, No. 79, 1987.

[17] M. H. Adabi and E. A. Mehmandost, "Microfacies and geochemistry of the Ilam formation in the Tang-Rashid area, Iran," Earth Science (Asian), Vol. 33, No. 3-4, 2008, pp. 267-227. doi:10.1016/j.jseaes.2008.01.002

[18] E. Ghaseminejad, M. H. Hobbi and P. Schiøler, "Dinoflagellate and Foraminiferal Biostratigraphy of the Gurpi Formation (Upper Santonian-Upper Maastrichtian), Zagros Mountains, Iran," Cretaceous Research, Vol. 27, No. 6, 2006, pp. 828-835. doi:10.1016/j.cretres.2006.03.013

[19] H. Blanco and R. Lal, "Principles of Soil Conservation and Management," Springer Publisher, New York, 2008.

[20] R. P. C. Morgan, "Soil Erosion and Conservation," Blackwell Publisher, Oxford, London, 2005.

[21] T. M. Parkner, M. Page, N. Marden and T. Marutani, "Gully Systems under Undisturbed Indigenous Forest, East Coast Region," Journal of Geomorphology (New Zealand), Vol. 84, No. 3-4, 2007, pp. 241-253. doi:10.1016/j.geomorph.2006.01.042

[22] P. P. Wani and R. Sudi, "Gully Control in SAT Watershed," International Crops Research Institute for the Semi-Arid Tropics, Hyderabad, 2006.

[23] C. Valentin, J. Poesen and Y. Li, "Gully Erosion: Impacts, Factors and Control," CATENA, Vol. 63, No. 2-3, 2005, pp. 132-153. doi:10.1016/j.catena.2005.06.001

[24] G. C. Ohlmacher, "The Relationship between Geology and Landslide Hazards of Atchison, Kansas and Vicinity," Kansas Geological Survey, Current Research in Earth Science, 2000. http://www.kgs.ukans.edu

[25] H. Ahmadi, "Applied Geomorphology," 2nd Edition, Tehran University Press, Tehran, 2003.

[26] H. E. Doner and W. Lynn, "Carbonate, Halide, Sulfate and Sulfide," In: J. M. Bighma, J. B. Dixon, M. H. Milford, C. B. Roth and S. B. Weed, Eds., Minerals in Soil Environments, American Society for Agronomy and the Soil Science Society of America, Madison, Wisconsin, 1989, pp. 539-580. 